\title{
Delyras - vienas iš daugelio COVID-19 veidų. Literatūros apžvalga
}

\author{
A. Bagdonaite ${ }^{*}$ \\ D. Tumas* \\ E. Griškevičiūtè** \\ A. Svirskyte் $\dot{e}^{* *}$ \\ *Respublikine Vilniaus psichiatrijos \\ ligonine, Alzheimerio ligos \\ ir somatopsichiatrijos skyrius; \\ Vilniaus universitetas, Medicinos \\ fakultetas, Klinikinès medicinos \\ institutas, Psichiatrijos klinika \\ **Vilniaus universitetas, \\ Medicinos fakultetas
}

\begin{abstract}
Santrauka. Neseniai išskirto SŪRS-CoV-2 sukeliamas COVID-19 šiuo metu yra itin aktualus, todèl labai svarbu kalbèti apie delyro ir atokesnių simptominių psichikos sutrikimų išsivystymą jo kontekste. Dažniausiai COVID-19 pasireiškia kosuliu, dusuliu ir karščiavimu, tačiau taip pat gali pasireikšti ir pakitusia sąmonès būsena, ypač vyresnio amžiaus pacientams, sergantiems sunkia ligos forma. Persirgę COVID-19 ligoniai dažnai patiria simptominių psichikos sutrikimų. Šio straipsnio tikslas - apžvelgti naujausią literatūrą apie COVID-19 infekcijos sukeliamus delyrus, jų epidemiologiją, patofiziologinius mechanizmus, prevencijos, diagnostikos ir gydymo galimybes. Tai padètų įvairių sričių specialistams, dirbantiems pandemijos metu, išsaugoti budrumą. Taip pat paminèti atokesnius simptominius psichikos sutrikimus, diagnozuojamus jau po persirgto COVID-19, kuriuos taip pat svarbu laiku atpažinti ir gydyti, nes tai gerina ligonių gyvenimo kokybę ir reabilitacijos eigą.

Raktažodžiai: delyras, COVID-19, vẻlyvosios psichiatrinės komplikacijos, antipsichotikai, melatoninas, valproinè rūgštis, simptominiai psichikos sutrikimai.
\end{abstract}

\section{IVADAS}

Delyras - tai ūminis, nespecifinis simptominis psichikos sutrikimas, viena sunkiausių, polimorfiškiausių, greitai kintančių psichozių, dažnai išsivystančių sergant įvairiausiomis fizinio kūno ligomis, ypač esant sunkioms ir kritinėms būklèms [1]. Dẻl savo polimorfiškumo delyras dažnai yra sunkiai atpažistama būklè. Savalaikis jo atpažinimas ir gydymas yra svarbūs palankesnei jị sukèlusios ligos eigai. Neseniai išskirto sunkų ūmų respiracinị sindromą sukeliančio koronaviruso 2 (SŪRS-CoV-2) sukeliama liga, pavadinta COVID-19, šiuo metu yra itin aktuali, todèl labai svarbu kalbeti apie delyro ir atokesnių, simptominių psichikos sutrikimų išsivystymą jos kontekste [2]. Dažniausiai COVID-19 pasireiškia kosuliu, dusuliu ir karščiavimu [3], taip pat gali pasireikšti ir pakitusia sąmonès bū-

\footnotetext{
Adresas:

Aušra Bagdonaite

Respublikine Vilniaus psichiatrijos ligonine,

Alzheimerio ligos ir somatopsichiatrijos skyrius

Parko g. 21, LT-11205 Vilnius

El.paštas bagdonaitei@gmail.com
}

sena, ypač vyresniems, sergantiems sunkesne ligos forma, pacientams [4]. Nustatyta, kad net $16 \%$ vyresnio amžiaus pacientų delyras gali būti pirmasis ligos simptomas. Daugiau nei trečdaliui jų gali nebūti jokių kitų tipinių COVID-19 klinikinių požymių [5]. COVID-19 metu yra itin svarbu laiku diagnozuoti delyrą, nes jo atsiradimas gali reikšti blogèjančią somatinę būklę. Šią sąmonès sutrikimo būseną gali sukelti hipoksija, taip pat toksinis ir metabolinis poveikis, sepsis bei uždegimas, tiesioginis infekcijos plitimas į centrinę nervų sistemą (CNS) [6]. Šio straipsnio tikslas - apžvelgti naujausią literatūrą apie COVID-19 sąlygotus delyrus, jų epidemiologiją, patofiziologinius mechanizmus, prevencijos ir gydymo galimybes. Tai padètų išsaugoti budrumą įvairių sričių specialistams, dirbantiems pandemijos metu. Taip pat paminèti atokesnius simptominius psichikos sutrikimus, diagnozuojamus jau po persirgto COVID-19, kuriuos taip pat svarbu laiku atpažinti ir gydyti, nes tai gerina ligonių gyvenimo kokybę ir reabilitacijos eigą.

(C) Neurologijos seminarai, 2020. Open Access. This article is distributed under the terms of the Creative Commons Attribution 4.0 International License CC-BY 4.0 (http://creativecommons.org/licenses/by/4.0/), which permits unrestricted use, distribution, and reproduction in any medium, provided you give appropriate credit to the original author(s) and the source, provide a link to the Creative Commons license, and indicate if changes were made. 


\section{EPIDEMIOLOGIJA}

Sąmonės sutrikimo būsenos dažnai manifestuoja tarp COVID-19 sergančių pacientų. Hospitalizacijos metu delyras buvo stebėtas $28 \%$ vyresnio amžiaus (65 m. ir vyresnių) pacientų. Tai buvo 6-asis dažniausias COVID-19 simptomas, o iš tų, kuriems nustatytas delyras, $16 \%$ pacientų tai buvo pagrindinis ligos simptomas [5]. Svarbu paminèti, kad COVID-19 pacientams, gydytiems reanimacijos skyriuje, delyras pasireiškẻ daug dažniau nei ịprastai (iki 80,2-84,3\%) [7,8]; 66,9 \% pacientų pasireiškè psichomotorinis sujaudinimas [7]. Delyrai dažniausiai buvo sunkūs [8].

\section{RIZIKOS FAKTORIAI}

Išskiriamos kelios COVID-19 sergančių pacientų delyro rizikos veiksnių grupès. Viena jų yra susijusi su pačiu pacientu: vyresniu amžiumi, gretutinèmis ligomis; kita - su COVID-19 eiga: tiesioginiu neurologiniu pažeidimu (pvz., tiesiogine CNS invazija virusu, encefalitu), netiesioginiais neurologiniais pažeidimais, smegenų hipoksija, galvos smegenų kraujagyslių pakitimais, daugine organų sistemų disfunkcija, ilgalaikiu karščiavimu, neurotransmiterių disbalansu, metaboliniais ir autoimuniniais pakitimais. Svarbios yra ir aplinkos veiksnių keliamos rizikos: izoliacija, ribotas bendravimas, asmens apsaugos priemonių naudojimas, dirbtinė plaučių ventiliacija (DPV), ilga hospitalizacijos trukmė, sutrikęs miegas, nejudrumas. Paskutinę rizikos grupę sudaro jatrogeniniai veiksniai: benzodiazepinų ir hipnotikų skyrimas, vidurių užkietėjimas, dehidratacija ir šlapimo susilaikymas [9].

\section{PATOFIZIOLOGIJA}

Svarstoma, kad sąmonès sutrikimus, sergant COVID-19, gali sukelti ịvairūs patofiziologiniai mechanizmai. Pažeidimai gali būti pirminiai - dèl tiesioginès CNS invazijos SŪRS-CoV-2, arba antriniai - dèl organų sistemų pažeidimų ir hipoksemijos. Dar išskiriami ir imuninio atsako (citokinų audros) sukelti smegenų pažeidimai [10-12].

Kalbant apie tiesioginę CNS invaziją, yra išskiriami keli pagrindiniai keliai, kuriais virusas gali pasiekti CNS. Vienas jų - nosies endotelyje esančio viruso gebejjimas prilipti prie motorinių baltymų, išsidèsčiusių šalia jutimo ir uoslès nervų, ir retrogradiniu aksoniniu transportu per kribriforminę plokštelę pasiekti smegenis. Tai siejama su gana dažnai pasitaikančiu simptomu - uoslès praradimu (anosmija) [13]. Alternatyvus kelias siejamas su infekavusio kvèpavimo takus SŪRS-CoV-2 išplitimu ì sisteminę kraujotaką. Koronavirusai turi dideli afinitetą angiotenziną konvertuojančio fermento 2 (AKF2) receptoriams. Viruso apvalkalo glikoproteinai padeda jam prisijungti prie šių receptorių, kurių gausu neuronuose ir endotelio ląstelèse. Taip virusas pereina plaučių parenchimą, patenka i kraujotaką ir pro hematoencefalinị barjerą prasiskverbia i CNS $[6,11]$.

Virusas taip pat gali iš žarnyno ar plaučių retrogradiškai judèti per aksoninị transportą ị smegenis. Gali pereiti hematoencefalinį barjerą kartu su užkrèstais leukocitais arba ji apeiti ir patekti i i smegenis per kraujagyslių endotelị [6]. Vykstant šiems procesams, degeneruoja smegenų neuronai [11].

Tais atvejais, kai smegenų skystyje virusas neaptinkamas, kalbame apie imuninio atsako sukeltus smegenu pažeidimus. Tikètina, kad SŪRS-CoV-2 sukelia imunologinị atsaką, kuris lemia parenchimos uždegimą. Vystosi smegenų edema ir encefalopatija [14]. Citokinai, perèję hematoencefalinị barjerą, tampa antrinès encefalopatijos priežastimi [10].

Dar vienas galimas patofiziologinis mechanizmas yra susijęs su COVID-19 metu pasireiškiančiu dusuliu ir hipoksija. Tiriant reanimacijos ir intensyviosios terapijos skyriuose (RITS) gydomus pacientus, pastebėtas ryšys tarp smegenų audinio hipoksijos ir delyro išsivystymo [15]. $\mathrm{O}_{2}$ homeostazè gali paveikti neuronų funkcijas, neurotransmiterių sintezės pokyčius [16]. Sumažèjusi smegenų audinio oksigenacija lemia didelị dopamino kiekio išskyrimą ir (ar) sumažejusią serotonino, acetilcholino sintezę, kurie gali sukelti delyrą [16-18].

Delyro patofiziologija yra daugiakomponentè, bet manoma, kad vienas svarbiausių vaidmenų tenka neurotransmiterių disbalansui. Ypač atkreipiamas dẻmesys ị acetilcholino trūkumą, dopamino ir noradrenalino, glutamato perteklių, serotonino, histamino, gama amino sviesto rūgšties kiekio svyravimus [19].

\section{DIAGNOSTIKA, GYDYMAS IR PREVENCIJA}

Apžvelgus priežastis, svarbu dar kartą kalbėti apie delyro polimorfiškumą, gydymą ir prevenciją.

Delyras pagal psichomotorini aktyvumą yra skirstomas į hipoaktyvų ir hiperaktyvų, ligos eigoje šie sąlyginiai tipai gali keisti vienas kitą [1], taip sukeldami dar daugiau diagnostinių keblumų. Bendrai ligonio būklei sunkèjant, gali prisidèti katatonijos simptomų, bylojančių apie letalinès išeities grèsmę [20].

Vieningų delyro gydymo gairių, pritaikytų COVID-19 sergantiems pacientams, trūksta. Siūloma laikytis iki pandemijos egzistavusių somatogeninio delyro gydymo gairių, jas pritaikant konkrečioms klinikinėms situacijoms, akcentuojant kvėpavimo sistemos pažeidimus, galimas vartojamų vaistų sąveikas. Toks delyro gydymas paprastai remiasi jo esminių sudedamųjų dalių, t. y. suvokimo, mąstymo, psichomotorinio elgesio, emocijų, miego ir budrumo ciklo bei kitų sutrikimų, korekcija [21].

Šiuo metu ị delyro simptomų farmakologinio gydymo rekomendacijas įeina melatoninas, antipsichotikai, valproatai, alfa-2 agonistai [9, 22, 23].

Melatoninas išskiriamas dẻl savo veikimo - jis reguliuoja miego ir budrumo ciklą, pasižymi neuroprotekciniu, 
priešuždegiminiu poveikiu (per smegenų neurotrofinio faktoriaus (BDNF) ekspresiją, glutamaterginès sistemos atenuaciją) ir antioksidaciniu poveikiu per glutationo kiekio išsaugojimą, turi imunitetą stiprinančių savybių, gali sumažinti citokinų audros formavimąsi. Šis vaistinis preparatas laikomas saugiu dèl reto šalutinio poveikio. Manoma, kad imunosupresuotiems pacientams melatonina reikètų skirti atsargiai [23]. Klinikinių tyrimų, patvirtinančių melatonino efektyvumą delyrui gydyti COVID-19 metu, nèra $[21,24]$.

Deksmedetomidinas yra labai selektyvus centrinio veikimo alfa-2 agonistas, turintis anksiolitinị, raminamajị ir skausmą malšinantị poveikị [25]. Jis laikomas itin tinkamu sedacijai COVID-19 pandemijos fone, nes neslopina kvèpavimo sistemos, taip pat mažina simpatinès nervų sistemos tonusą. Taip pat deksmedetomidinas mažina noradrenalino kiekị tiek CNS, tiek periferinëje nervų sistemoje [24, 26].

Gydant somatogeninius delyrus, yra svarbūs įvairūs antipsichotikai. Renkantis antipsichotiką, būtina atsižvelgti ị konkrečią klinikinę situaciją, galimus šalutinius reiškinius, anticholinerginį, sedacinį veikimą, teikiant pirmenybę mažesnès potencijos „silpnesniems“, atipiniams antipsichotikams, pradedant nuo mažų dozių, kurios titruojamos pagal toleranciją ir terapini atsaką. Paminètina, kad hipoaktyviam delyrui rekomenduojamas aripiprazolis, hiperaktyviam - kvetiapinas, olanzapinas, risperidonas ir kt. Atkreipiamas demesys, kad reikètų atsargiai skirti haloperidoli. Tiapridas - labiau tinkamas antipsichotikas ne RITS [23, 24]. Svarbu pabrèžti, kad benzodiazepinus reikètų vartoti labai atsargiai [9, 22, 23].

Dèl CNS oksidacinio streso, taip pat ir neurotoksiškumo prevencijai, galima skirti valproatų. Aprašoma potenciali valproatų nauda gydant hiperaktyvius ir mišrius delyrus. Manoma, kad valproatai pasižymi priešuždegiminiu, neuroprotekciniu, antioksidaciniu poveikiu, veikdami per dopamino, glutamato, noradrenalino apykaitą, potencialiai mažina citokinų audroje dalyvaujančio interleukino-6 transkripciją, taip pat gali mažinti sedacinių vaistų poreikị. Juos skiriant, svarbu atkreipti dèmesi ị galimas vaistų sąveikas. Klinikinių tyrimų, patvirtinančių valproinès rūgšties efektyvumą delyrui gydyti COVID-19 metu, taip pat nèra $[21,24]$.

Akcentuojama nemedikamentinès delyro prevencijos ir gydymo įvairių grupių vaistais svarba, rekomenduojama ją taikyti, kai tik tai įmanoma, COVID-19 metu [11]. Iš nemedikamentinių priemonių išskiriama kaip įmanoma trumpesnis DPV taikymas, nuolatinė pacientų reorientacija, ankstyvas mobilumas, profesionali psichologinè pagalba, kuri turètų būti teikiama tiek pacientui, tiek jo artimiesiems, tiek skyriuje dirbantiems medikams. Svarbu nepamiršti ir, esant galimybei, taikyti nuotolinị pacientų bendravimą su artimaisiais $[9,11,27]$. Labai svarbus vaidmuo taip pat tenka adekvačiam skausmo valdymui, tinkamai parinktai sedacijai. Rekomenduojama vengti anticholinerginị poveikị, dopaminerginị poveikị turinčių vaistų, benzodiazepinų, opioidų, nes jie taip pat gali sukelti delyro išsivystymą [24].

\section{PROGNOZE்}

Atkreipiamas dèmesys, kad patyrusiujų delyrą sveikimo prognozė skiriasi nuo jo nepatyrusiųju. Lyginant COVID-19 pacientus, gydytus RITS ir kuriems pasireiškẻ delyras, ir pacientus, kuriems ši simptomatika nebuvo stebėta, apskaičiuota, kad DPV delyro grupejje buvo taikoma 4 dienomis ilgiau (vidutiniškai 14 ir 10 dienų). Delyrą patyrę pacientai RITS praleido maždaug 5 dienomis ilgiau. Pažymėtina, kad pacientų, kuriems pasireiškè delyras, gydymas dažniau baigèsi letalia išeitimi, kuri siekè $16,1 \%$, palyginus su 9,1\% tarp kitų pacientų [7].

\section{ATOKESNI SIMPTOMINIAI COVID-19 PACIENTU PSICHIKOS SUTRIKIMAI}

Ankstesnių studijų (iki COVID-19 pandemijos) metu nustatyta, kad daugiau nei $50 \%$ pacientų, gydytų RITS dèl kritinès būklès, pasireiškia ilgalaikiai atokesni simptominiai psichikos sutrikimai [28]. Pacientams po išrašymo aprašomas PICS (angl. post intensive care syndrome) - kognityvinių funkcijų, psichinès sveikatos ir fizinès būklès silpimas, kuris gali užsitęsti daugiau nei metus. Pastebèta, kad apie 60 \% COVID-19 sirgusių pacientų per vienerius metus po gydymo RITS atsiranda vėlyvosios psichiatrinès komplikacijos - depresija (14,9\%), nerimas (14,8 \%), potrauminio streso sindromas $(32,2 \%)$. Išsivysto ir fiziniai sutrikimai (angl. intensive care unit acquired weakness (ICUAW) - silpnumas po gydymo RITS) [9, 11]. Svarbu, kad vienatvès ir izoliacijos jausmas gali pabloginti savijautą, pagilinti depresijos simptomus, kelti nerimą ir pyktic. Tai gali sukelti apatiją, skatinti neveiklumą, neaktyvumą ir didinti delyro išsivystymo riziką, ypač vyresnio amžiaus hospitalizuotiems RITS pacientams [11].

Atliktos studijos leidžia įžvelgti poreikị vykdyti pasveikusių nuo COVID-19 asmenų stebẻjimą dèl galimų ilgalaikių simptominių psichikos sutrikimų pasekmių ir taikyti ankstyvas intervencijos priemones, siekiant pagerinti šių asmenų atokaus gydymo rezultatus. PICS gydymas susideda iš kelių punktų: a) sutrikimus sukeliančių faktorių eliminavimas ar koregavimas, b) tinkamas vaistų skyrimas, c) streso eliminavimas iš paciento aplinkos, d) dažnas šeimos ir paciento bendravimas.

Išskiriama, kad geriausias PICS gydymas yra prevencinis. Jis reikalauja multidisciplininès komandos darbo. Svarbiausia riboti gilios sedacijos naudojimą, skatinti ankstyvą paciento mobilumą ir įtraukti ị fizinę bei užimtumo terapijas [29].

Atsižvelgiama ir į tai, kad liga paveikia ne tik pacientą, bet ir jo šeimą. Yra aprašomas PICS-F (angl. post intensive care syndrome - family), kuris apibūdina ūmini ir lètinị kritinès ligos poveiki pacientų šeimai. Jis apima šeimos narių patiriamus simptomus kritinès ligos metu, taip pat simptomus, atsirandančius po artimo žmogaus mirties ar jo išrašymo ị namus [29]. Tad COVID-19 pandemijos metu išlieka aktuali ir pacientų artimųjų psichologinè būklè. 


\section{IŠVADOS}

Delyras dažnai pasireiškia COVID-19 atveju, ypač vyresnio amžiaus pacientams, sergantiems sunkesne ligos forma, turintiems daugiau gretutinių ligų. Svarbu, kad tai gali būti pirmasis ar net pagrindinis ligos požymis. Kol kas dar nėra sukaupta pakankamai duomenų, kad būtų sudarytos ir patvirtintos delyro, sergant COVID-19, diagnostikos ir gydymo gairès, todèl svarbu pritaikyti ir naudoti bendras simptominių somatogeninių delyrų gydymo rekomendacijas. Atsižvelgiant į didelį delyro paplitimą tarp COVID-19 pacientų, svarbu atkreipti dėmesi i i prevenciją, siekti kuo ankstyvesnès delyro diagnostikos, savalaikès medikamentinès ir nemedikamentinès intervencijos, kas sąlygotu geresnius ilgalaikius gydymo rezultatus. Ne mažiau svarbu diagnozuoti ir gydyti atokesnius simptominius psichikos sutrikimus, dar kitaip vadinamus vèlyvomis psichiatrinèmis komplikacijomis, kas gerintų persirgusių pacientų gyvenimo kokybę ir reabilitacijos eigą.

\section{Literatūra}

1. Inouye SK, Westendorp RG, Saczynski JS. Delirium in elderly people. Lancet 2014; 383(9920): 911-22. https://doi.org/10.1016/S0140-6736(13)60688-1

2. Matheson NJ, Lehner PJ. How does SARS-CoV-2 cause COVID-19? Science 2020; 369(6503): 510-1. https://doi.org/10.1126/science.abc6156

3. Docherty AB, Harrison EM, Green CA, Hardwick HE, Pius R, Norman L, et al. Features of 20133 UK patients in hospital with covid-19 using the ISARIC WHO Clinical Characterisation Protocol: prospective observational cohort study. BMJ 2020; 369: m1985. https://doi.org/10.1136/ bmj.m1985

4. Romero-Sánchez CM, Díaz-Maroto I, Fernández-Díaz E, Sánchez-Larsen Á, Layos-Romero A, García-García J, et al. Neurologic manifestations in hospitalized patients with COVID-19: the ALBACOVID registry. Neurology 2020; 95(8): e1060-70. https://doi.org/10.1212/WNL. 0000000000009937

5. Kennedy M, Helfand BKI, Gou RY, Gartaganis SL, Webb M, Moccia JM, et al. Delirium in older patients with COVID-19 presenting to the emergency department. JAMA Netw Open 2020; 3(11): e2029540. https://doi.org/10.1001/ jamanetworkopen.2020.29540

6. Garg RK, Paliwal VK, Gupta A. Encephalopathy in patients with COVID-19: a review. J Med Virol 2021; 93(1): 206-22. https://doi.org/10.1002/jmv.26207

7. Helms J, Kremer S, Merdji H, Schenck M, Severac F, Clere-Jehl R, et al. Delirium and encephalopathy in severe COVID-19: a cohort analysis of ICU patients. Crit Care 2020; 24(1): 491. https://doi.org/10.1186/ s13054-020-03200-1

8. Khan SH, Lindroth H, Perkins AJ, Jamil Y, Wang S, Roberts $\mathrm{S}$, et al. Delirium incidence, duration, and severity in critically ill patients with coronavirus disease 2019. Crit Care Explor 2020; 2(12): e0290. https://doi.org/10.1097/ CCE. 0000000000000290

9. Emmerton D, Abdelhafiz A. Delirium in older people with COVID-19: clinical scenario and literature review.
SN Compr Clin Med 2020; 2(10): 1790-7. https://doi.org/ 10.1007/s42399-020-00474-y

10. Beach SR, Praschan NC, Hogan C, Dotson S, Merideth F, Kontos N, et al. Delirium in COVID-19: a case series and exploration of potential mechanisms for central nervous system involvement. Gen Hosp Psychiatry 2020; 65: 47-53. https://doi.org/10.1016/j.genhosppsych.2020.05.008

11. Kotfis K, Williams Roberson S, Wilson J, Pun B, Ely EW, Jezowska I, et al. COVID-19: what do we need to know about ICU delirium during the SARS-CoV-2 pandemic? Anaesthesiol Intensive Ther 2020; 52(2): 132-8. https://doi.org/10.5114/ait.2020.95164

12. Azizi SA, Azizi S-A. Neurological injuries in COVID-19 patients: direct viral invasion or a bystander injury after infection of epithelial/endothelial cells. J Neurovirol 2020; 26(5): 631-41. https://doi.org/10.1007/ s13365-020-00903-7

13. Achar A, Ghosh C. COVID-19-associated neurological disorders: the potential route of CNS invasion and blood-brain barrier relevance. Cells 2020; 9(11): 2360. https://doi.org/ 10.3390/cells9112360

14. Hosseini AA, Shetty AK, Sprigg N, Auer DP, Constantinescu CS. Delirium as a presenting feature in COVID-19: neuroinvasive infection or autoimmune encephalopathy? Brain Behav Immun 2020; 88: 68-70. https://doi.org/10.1016/j.bbi.2020.06.012

15. Wood MD, Maslove DM, Muscedere JG, Day AG, Gordon Boyd J. Low brain tissue oxygenation contributes to the development of delirium in critically ill patients: a prospective observational study. J Crit Care 2017; 41: 289-95. https://doi.org/10.1016/j.jcrc.2017.06.009

16. Kumar GK. Hypoxia. 3. Hypoxia and neurotransmitter synthesis. Am J Physiol-Cell Physiol 2011; 300(4): C743-51. https://doi.org/10.1152/ajpcell.00019.2011

17. Barath AS, Rusheen AE, Rojas Cabrera JM, Price JB, Owen RL, Shin H, et al. Hypoxia-associated changes in striatal tonic dopamine release: real-time in vivo measurements with a novel voltammetry technique. Front Neurosci 2020; 14: 869. https://doi.org/10.3389/fnins.2020.00869

18. Maldonado JR. Delirium in the acute care setting: characteristics, diagnosis and treatment. Crit Care Clin 2008; 24(4): 657-722. https://doi.org/10.1016/j.ccc.2008.05.008

19. Maldonado JR. Delirium pathophysiology: an updated hypothesis of the etiology of acute brain failure. Int J Geriatr Psychiatry 2018; 33(11): 1428-57. https://doi.org/10.1002/ gps. 4823

20. Grover S, Ghosh A, Ghormode D. Do patients of delirium have catatonic features? An exploratory study: catatonic symptoms in delirium. Psychiatry Clin Neurosci 2014; 68(8): 644-51. https://doi.org/10.1111/pcn.12168

21. Hawkins M, Sockalingam S, Bonato S, Rajaratnam T, Ravindran M, Gosse P, et al. A rapid review of the pathoetiology, presentation, and management of delirium in adults with COVID-19. J Psychosom Res 2021; 141: 110350. https://doi.org/10.1016/j.jpsychores. 2020.110350

22. Cipriani G, Danti S, Nuti A, Carlesi C, Lucetti C, Di Fiorino M. A complication of coronavirus disease 2019: delirium. Acta Neurol Belg 2020; 120(4): 927-32. https://doi.org/10.1007/s13760-020-01401-7

23. Baller EB, Hogan CS, Fusunyan MA, Ivkovic A, Luccarelli JW, Madva E, et al. Neurocovid: pharmacological recommendations for delirium associated with COVID-19. 
Psychosomatics 2020; 61(6): 585-96. https://doi.org/ 10.1016/j.psym.2020.05.013

24. Ostuzzi G, Gastaldon C, Papola D, Fagiolini A, Dursun S, Taylor D, et al. Pharmacological treatment of hyperactive delirium in people with COVID-19: rethinking conventional approaches. Ther Adv Psychopharmacol 2020; 10: 204512532094270. https://doi.org/10.1177/ 2045125320942703

25. Park SY, Lee HB. Prevention and management of delirium in critically ill adult patients in the intensive care unit: a review based on the 2018 PADIS guidelines. Acute Crit Care 2019; 34(2): 117-25. https://doi.org/10.4266/acc.2019.00451

26. Su X, Meng Z-T, Wu X-H, Cui F, Li H-L, Wang D-X, et al. Dexmedetomidine for prevention of delirium in elderly patients after non-cardiac surgery: a randomised, double-blind, placebo-controlled trial. Lancet 2016; 388(10054): 1893-902. https://doi.org/10.1016/ S0140-6736(16)30580-3

27. Kotfis K, Williams Roberson S, Wilson JE, Dabrowski W, Pun BT, Ely EW. COVID-19: ICU delirium management during SARS-CoV-2 pandemic. Crit Care 2020; 24(1): 176. https://doi.org/10.1186/s13054-020-02882-x

28. Hatch R, Young D, Barber V, Griffiths J, Harrison DA, Watkinson P. Anxiety, depression and post traumatic stress disorder after critical illness: a UK-wide prospective cohort study. Crit Care 2018; 22(1): 310. https://doi.org/10.1186/ s13054-018-2223-6

29. Rawal G, Yadav S, Kumar R. Post-intensive care syndrome: an overview. J Transl Intern Med 2017; 5(2): 90-2. https://doi.org/10.1515/jtim-2016-0016
A. Bagdonaitė, D. Tumas, E. Griškevičiūtè, A. Svirskytė

\section{DELIRIUM IS ONE OF THE MANY FACES OF COVID-19. LITERATURE REVIEW}

\section{Summary}

Taking into account today's context of COVID-19 disease, it is very important to acknowledge the serious psychiatric complications that arise during the acute phase of the disease, as well as those that have a delayed onset and are no less dangerous. COVID-19 is most commonly associated with cough, shortness of breath, and fever; however, changes in consciousness can also occur, especially in elderly patients with severely advanced disease. COVID-19 recovered patients often experience symptomatic mental disorders. The purpose of this article is to review the recent literature on COVID-19 induced delirium, its epidemiology, pathophysiological mechanisms, prevention, diagnostic and treatment options. The expectation is that this would help maintain clinical vigilance of healthcare professionals working during the global pandemic. Mention should also be made of the delayed-onset symptomatic psychiatric disorders that occur after recovery from COVID-19 disease, which are also important to recognize and treat in a timely manner, as they impair patients' quality of life and the course of rehabilitation.

Keywords: delirium, COVID-19, delayed-onset psychiatric complications, antipsychotic, melatonin, valproic acid, symptomatic mental disorders.

Gauta:

20201215

Priimta spaudai: 20201231 